University of Nebraska - Lincoln

DigitalCommons@University of Nebraska - Lincoln

USDA National Wildlife Research Center - Staff Publications
U.S. Department of Agriculture: Animal and Plant Health Inspection Service

2020

\title{
Placebo Oral Rabies Vaccine Bait Uptake by Small Indian Mongooses (Herpestes auropunctatus) in Southwestern Puerto Rico
}

\author{
Are R. Berentsen \\ National Wildlife Research Center, Fort Collins, CO, Are.R.Berentsen@aphis.usda.gov \\ Richard B. Chipman \\ USDA National Rabies Management Program, richard.b.chipman@usda.gov \\ Kathleen M. Nelson \\ USDA National Rabies Management Program, kathleen.m.nelson@usda.gov \\ Kenneth S. Gruver \\ USDA APHIS, Auburn, AL, Kenneth.S.Gruver@aphis.usda.gov

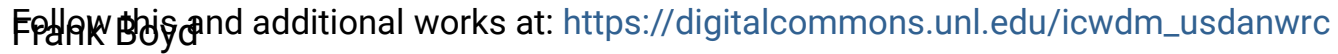

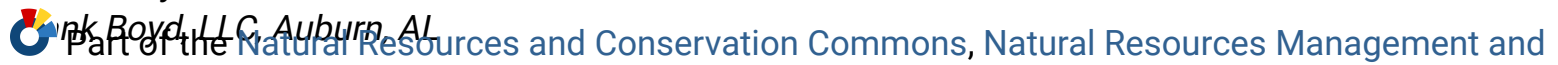 \\ Policy Commons, Other Environmental Sciences Commons, Other Veterinary Medicine Commons,

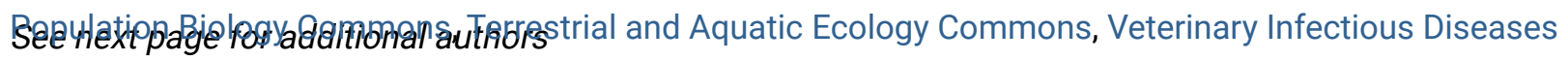 \\ Commons, Veterinary Microbiology and Immunobiology Commons, Veterinary Preventive Medicine, \\ Epidemiology, and Public Health Commons, and the Zoology Commons
}

Berentsen, Are R.; Chipman, Richard B.; Nelson, Kathleen M.; Gruver, Kenneth S.; Boyd, Frank; Volker, Steven F.; Davis, Amy J.; Vos, Ad; Ortmann, Steffen; and Gilbert, Amy, "Placebo Oral Rabies Vaccine Bait Uptake by Small Indian Mongooses (Herpestes auropunctatus) in Southwestern Puerto Rico" (2020). USDA National Wildlife Research Center - Staff Publications. 2339.

https://digitalcommons.unl.edu/icwdm_usdanwrc/2339

This Article is brought to you for free and open access by the U.S. Department of Agriculture: Animal and Plant Health Inspection Service at DigitalCommons@University of Nebraska - Lincoln. It has been accepted for inclusion in USDA National Wildlife Research Center - Staff Publications by an authorized administrator of DigitalCommons@University of Nebraska - Lincoln. 


\section{Authors}

Are R. Berentsen, Richard B. Chipman, Kathleen M. Nelson, Kenneth S. Gruver, Frank Boyd, Steven F. Volker, Amy J. Davis, Ad Vos, Steffen Ortmann, and Amy Gilbert 


\title{
Placebo Oral Rabies Vaccine Bait Uptake by Small Indian Mongooses (Herpestes auropunctatus) in Southwestern Puerto Rico
}

\begin{abstract}
Are R. Berentsen, ${ }^{1,6}$ Richard B. Chipman, ${ }^{2}$ Kathleen M. Nelson, ${ }^{2}$ Kenneth S. Gruver, ${ }^{3}$ Frank Boyd, ${ }^{4}$ Steven F. Volker, ${ }^{1}$ Amy J. Davis, ${ }^{1}$ Ad Vos,${ }^{5}$ Steffen Ortmann, ${ }^{5}$ and Amy T. Gilbert ${ }^{1}{ }^{1}$ US Department of Agriculture, Animal and Plant Health Inspection Service, Wildlife Services, National Wildlife Research Center, 4101 LaPorte Ave., Fort Collins, Colorado 80521, USA; ${ }^{2}$ US Department of Agriculture, Animal and Plant Health Inspection Service, Wildlife Services, National Rabies Management Program, 59 Chenell Dr., Suite 2, Concord, New Hampshire 03301, USA; ${ }^{3}$ US Department of Agriculture, Animal and Plant Health Inspection Service, Wildlife Services, 602 Duncan Dr., Auburn, Alabama 36849, USA; ${ }^{4}$ Frank Boyd, LLC, 1242 Pinebrook Cir., Auburn, Alabama 36830, USA; ${ }^{5}$ Ceva Santé Animale, Am Pharmapark, 06846 Dessau-Rosslau, Germany; ${ }^{6}$ Corresponding author (email: Are.R.Berentsen@usda.gov)
\end{abstract}

ABSTRACT: The small Indian mongoose (Herpestes auropunctatus) is a rabies reservoir in areas of the Caribbean including Puerto Rico, but no rabies vaccination program targeting this host exists. We used two derivatives of iophenoxic acid (IPA) to evaluate placebo oral rabies vaccine bait uptake by mongooses in southwestern Puerto Rico. We hand-distributed baits at an application rate of $200 \mathrm{baits} / \mathrm{km}^{2}$ at three, $400 \mathrm{ha}$, sites during autumn 2016 and spring 2017. Each site contained 90-100 cage traps in a 100 ha central trapping area. We used ethyl-IPA as a biological marker during the autumn and methyl-IPA during the spring. We live captured mongooses for 10 consecutive days, beginning $1 \mathrm{wk}$ following bait application. We obtained a serum sample from captured mongooses and analyzed the sera for ethyl- and methyl-IPA by liquid chromatographymass spectrometry. During autumn 2016, 63\% (55/87) mongooses sampled were positive for ethyl-IPA. In spring 2017, 69\% (85/123) of mongooses were positive for methyl-IPA. Pooling seasons, accounting for recaptures between years, and disregarding marker type, 74\% (133/179) unique mongooses were positive for IPA biomarker, indicating bait consumption during either the autumn, spring, or both trials. We conclude that distributing baits at an application rate of 200 baits $/ \mathrm{km}^{2}$ is sufficient to reach over $60 \%$ of the target mongoose population in dry forest habitats of Puerto Rico.

Key words: Herpestes auropunctatus, iophenoxic acid, oral rabies vaccination, Puerto Rico, rabies, small Indian mongoose.

The small Indian mongoose (Herpestes auropunctatus) is a rabies reservoir on several Caribbean islands (Seetahal et al. 2018) and accounts for over $50 \%$ of animal rabies cases in Puerto Rico (Ma et al. 2018). In Puerto Rico, the first laboratory confirmed case of rabies in mongooses was in 1950 (Tierkel et al.
1952). There have been two documented human fatalities from mongoose-related rabies in Puerto Rico in the 21st century: the first in 2003, the most recent in 2015 (Ma et al. 2018).

Control of rabies virus circulation in wild carnivore populations is cooperatively managed by state and local public health departments and the US Department of Agriculture National Rabies Management Program, principally using a strategy of oral rabies vaccination (ORV; Slate et al. 2005). However, no ORV program targeting mongooses exists in the Caribbean. Oral rabies vaccine development research for mongooses was conducted in the early 2000s (Blanton et al. 2006) and evaluated the efficacy of the vaccinia-rabies glycoprotein RABORAL V-RG ${ }^{\circledR}$ (Boehringer Ingelheim Animal Health, Athens, Georgia, USA) and an experimental recombinant rabies virus vaccine (SPBNGA-S). Results from Blanton et al. (2006) suggest that RABORAL $\mathrm{V}-\mathrm{RG}$ is not efficacious for mongooses, but study subjects vaccinated with SPBNGA-S seroconverted and survived a lethal challenge with rabies virus. This research motivated the development of a new vaccine with a similar construct (SPBN GASGAS), which was later reported to be immunogenic for mongooses (Vos et al. 2013).

An effective ORV program requires a vaccine-bait combination with proven efficacy for the target species and safety for both target and nontarget species. In addition, recommended background ecological data for target and nontarget species include population densities and natural levels of 


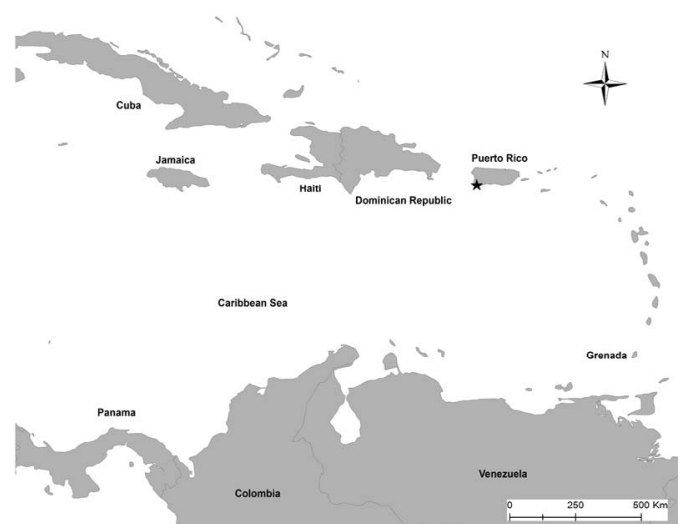

Figure 1. Location of Puerto Rico in the Caribbean Sea relative to other nations in the region. The black star represents the study location in southwestern Puerto Rico.

rabies virus neutralizing antibodies (RVNAs) in target populations, as well as an effective vaccine delivery system (appropriate bait shape, flavor, etc.). In Puerto Rico, mongoose population densities range from 0.44 to 0.75 / ha in select forested habitats (Johnson et al. 2016), and RVNA seroprevalence up to $39 \%$ has been documented in some regions (Berentsen et al. 2015). Bait preference trials have been conducted (Berentsen et al. 2014, 2017), and recent research suggests rodents (primarily black rats, Rattus rattus) are a primary bait competitor (Berentsen et al. 2017). In Puerto Rico, mongooses breed throughout the year, but two birth pulses (March-April and July-August) are typically observed with two to four pups per litter (Pimentel 1955).

To demonstrate an effective vaccine-bait delivery system and strategy, it is necessary to measure bait uptake by the target species. In the US, this is typically accomplished by evaluating RVNA seroprevalence and bait biomarker prevalence pre- and postbaiting in the target population (Pedersen et al. 2019). Iophenoxic acid (IPA) is a white, crystalline powder used as a biological marker with numerous mammalian species (Ballesteros et al. 2013). Laboratory trials in mongooses found IPA concentrations in serum remained above the level of quantification for at least $8 \mathrm{wk}$ postbait consumption (Berentsen et al. 2019), which suggests suitabil-

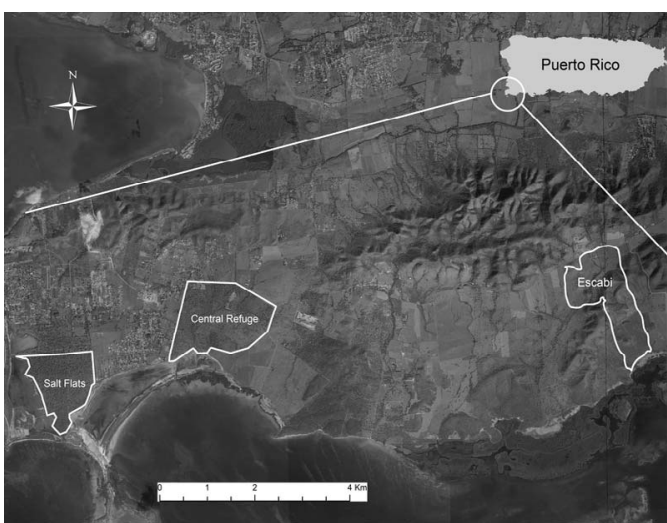

Figure 2. Precise location of the Central Refuge, Salt Flats, and Escabi study sites in southwestern Puerto Rico during the autumn 2016 and spring 2017 placebo oral rabies vaccination bait applications.

ity as a short- to medium-term biological marker to measure uptake in the field.

Our objective was to use two derivatives of IPA: 2-(3-hydroxy-2,4,6-triiodobenzyl)butanoic acid (ethyl-IPA) and a methyl substituted derivative (2-(3-hydroxy-2,4,6-triiodobenzyl)propanoic acid; methyl-IPA), to evaluate placebo ORV bait uptake rates by free-ranging mongooses following hand distribution at 2 baits/ha across three sites in southwestern Puerto Rico during the autumn and spring. We hypothesized that the targeted application rate would be sufficient to reach at least $30 \%$ of the mongoose population based on preliminary bait disappearance studies with two flavors of this placebo bait in the same study areas and slightly lower application rate.

We conducted this study on the island of Puerto Rico (Fig. 1). We established three study plots: Salt Flats and Central Refuge on the Cabo Rojo National Wildlife Refuge, Cabo Rojo Municipality, and Escabi on private land in Lajas Municipality (Fig. 2). Dominant habitat type is classified as subtropical dry forest (Diaz 2011). We conducted this study during autumn 2016 and spring 2017 to accommodate potential seasonal bait uptake differences as a result of differing mongoose population densities between seasons (Johnson et al. 2016).

Baits consisted of a $0.7 \mathrm{~mL}$ water-filled foil blister pack surrounded by an outer bait matrix 
TABLE 1. Total number of small Indian mongooses (Herpestes auropunctatus) captured across three study sites during a $10 \mathrm{~d}$ period in autumn 2016 following the distribution of marked placebo baits at a rate of $200 \mathrm{baits} / \mathrm{km}^{2}$ in southwestern Puerto Rico. The number of mongoose sera obtained from captured animals and the subset testing positive for the detection of the ethyl-iophenoxic acid (ethyl-IPA) placebo bait marker residue is reported. Study locations included the Salt Flats and Central Refuge on the Cabo Rojo National Wildlife Refuge, Cabo Rojo Municipality, and one plot on private land (Escabi) in Lajas Municipality.

\begin{tabular}{lcccr}
\hline & & Study site & & \\
\cline { 2 - 4 } & Central refuge & Salt flats & Escabi & Total \\
\hline No. animals captured & 38 & 39 & 23 & 100 \\
No. sera collected and tested for biomarker & 35 & 32 & 20 & 87 \\
No. sera testing positive for ethyl-IPA & 22 & 22 & 11 & 55 \\
\hline
\end{tabular}

composed of gelatin and powdered chicken egg (Ceva Santé Animale, Dessau-Rosslau, Germany), a preferred bait flavor in field and laboratory trials (Vos et al. 2013; Berentsen et al. 2018). The outer bait matrix contained 2.8 mg of either ethyl-IPA (autumn 2016) or methyl-IPA (spring 2017). We established a 400 ha baiting plot at each location, consisting of a 100 ha central trapping area, surrounded by a $500 \mathrm{~m}$ buffer zone. We hand-distributed baits throughout each plot at an application rate of 2 baits/ha by walking along eight, $2 \mathrm{~km}$ transects, $250 \mathrm{~m}$ apart and deposited a single bait every $20 \mathrm{~m}$. All trap and bait locations were predetermined and loaded onto a handheld GPS unit. We distributed baits in the morning about $1 \mathrm{~h}$ after sunrise to maximize bait availability to diurnal mongooses and reduce potential nontarget bait consumption by nocturnal rodents. Trapping commenced 7-9 d following bait application.

We live captured mongooses in $15 \times 15 \times 63$ $\mathrm{cm}$ cage traps (Tomahawk Trap Company, Hazelhurst, Wisconsin, USA) baited with canned tuna. We placed 100 traps $(10 \times 10$ grid) at the Salt Flats and the Central Refuge and 90 (5×18 grid) at Escabi. We placed traps $100 \mathrm{~m}$ apart during the morning and checked them daily for $10 \mathrm{~d}$. We anesthetized captured mongooses via intramuscular injection of $5 \mathrm{mg} /$ $\mathrm{kg}$ Telazol (tiletamine/zolazepam; Kreeger and Arnemo 2012). We marked each mongoose by subcutaneous injection of a uniquely numbered passive integrated transponder tag (Avid Identification Systems, Norco, California, USA) to identify recaptures. We collected about $1 \mathrm{~mL}$ of whole blood by venipuncture of the cranial vena cava (Briscoe and Syring 2004). We centrifuged blood samples in serum separator tubes at $670 \times \mathrm{G}$ for $15-20 \mathrm{~min}$, decanted the serum into cryovials, and stored them at $-20 \mathrm{C}$ and then $-80 \mathrm{C}$ until analysis.

We tested individual mongoose serum for methyl-IPA and ethyl-IPA using the liquid chromatography-mass spectrometry method described in Berentsen et al. (2019) with the following modifications: we used propyl-IPA as the surrogate analyte to quantify both methyl-IPA and ethyl-IPA. For propyl-IPA, the quantifier MRM (multiple reaction monitoring) transition was $584.7 \rightarrow 456.8$, fragmentor $89 \mathrm{~V}$, and collision energy $14 \mathrm{~V}$. For ethylIPA, the qualifier MRM transition was $570.7 \rightarrow 126.8$, fragmentor $87 \mathrm{~V}$, and collision energy $61 \mathrm{~V}$. Control mongoose serum was fortified with both methyl-IPA and ethyl-IPA at $1.3,31$, and $83 \mu \mathrm{g} / \mathrm{mL}(n=27)$. Percent recoveries for methyl-IPA ranged from $105 \%$ to $118 \%$, and $98.5 \%$ to $118 \%$ for ethyl-IPA. The signal-to-noise ratio was calculated from the average baseline noise observed in nine control sera, and the average peak height observed in nine control sera fortified with 1.3 $\mu \mathrm{g} / \mathrm{mL}$ me-/et-IPA. The detection limit was estimated as the IPA concentration in serum equivalent to three times the signal-to-noise ratio. The detection limit was $0.042 \mu \mathrm{g} / \mathrm{mL}$ for methyl-IPA and $0.041 \mu \mathrm{g} / \mathrm{mL}$ for ethyl-IPA.

Among 87 mongooses sampled during 2016, 63\% (95\% CI: 53-73\%) were positive for ethylIPA (Table 1). Among 123 mongooses sampled during 2017, 69\% (95\% CI: 60-77\%) were 
TABLE 2. The small Indian mongoose (Herpestes auropunctatus) capture/recapture results from spring 2017 after 1000 trap nights each at the Salt Flats and Refuge and 900 trap nights at Escabi. Also shown is the number of animals positive for either or both iophenoxic acid (IPA) derivatives and those that were negative.

\begin{tabular}{lcrrr}
\hline & & Study site & & \\
& \multicolumn{1}{c}{ Central refuge } & Salt flats & Escabi & Total \\
\cline { 2 - 4 } Captured & 53 & 43 & 39 & 135 \\
Sampled & 46 & 42 & 35 & 123 \\
Positive ethyl-IPA & 23 & 28 & 20 & 71 \\
Positive methyl-IPA & 26 & 36 & 23 & 85 \\
Positive ethyl-IPA only & 5 & 4 & 5 & 11 \\
Positive methyl-IPA only & 8 & 12 & 18 & 25 \\
Positive ethyl- and methyl-IPA & 18 & 24 & 25 & 60 \\
Positive either ethyl- or methyl-IPA & 31 & 40 & 10 & 96 \\
Negative & 15 & 2 & 7 & 27 \\
Recaptures from 2016 & 14 & 9 & $30^{\mathrm{a}}$ \\
\hline
\end{tabular}

a The total number of recaptures at each site between years. The pooled number of recapture events across all sites was 31 as one mongoose was captured at the Central Refuge in 2016 and at the Salt Flats ( 4.0 km away) in 2017.

positive for methyl-IPA, 48\% (95\% CI: 40$58 \%$ ) were positive for methyl- and ethyl-IPA, and $77 \%$ (95\% CI: $70-84 \%$ ) were positive for either or both biomarkers (Table 2). Pooling samples across years and accounting for 31 recaptures that were sampled during both years, we sampled 179 individual mongooses. We counted each recapture as positive or negative only once regardless of the sampling year. Disregarding which IPA derivative was found and classifying mongooses simply as marked or unmarked, 74\% (95\% CI: 68-80\%) of 179 mongooses were positive for IPA. Additional figures and capture details are found in the Supplementary Material.

Bait uptake rates observed in this study suggest an application rate of 2 baits/ha is sufficient to reach over $60 \%$ of the mongoose population in this habitat, consistent with the general recommendation of $60-90 \%$ vaccination to interrupt rabies virus transmission in some wildlife species (Thulke and Eisinger 2008). Additional studies optimizing vaccine bait densities in other habitats and using alternate distribution methods (including rotary wing distribution and bait stations) can enhance a future integrated ORV program targeting mongooses in Puerto Rico.

This research was supported in part by the US Department of Agriculture, Animal and
Plant Health Inspection Service, Wildlife Services, National Rabies Management Program, and Ceva Santé Animale (DessauRosslau, Germany). All animal use was in compliance with the guidelines of the Institutional Animal Care and Use Committee of the US Department of Agriculture National Wildlife Research Center, protocol QA-2573, and authorized by the Puerto Rico Department of Natural and Environmental Resources (scientific collection permit 201-IC-149) and the US Fish and Wildlife Service Cabo Rojo National Wildlife Refuge (special use permits 41521-2016-17 and 41521-2017-09). Conflict of interest statement: A.V. and S.O. are fulltime employees of an oral rabies vaccine bait manufacturer. The authors wish to thank R. Lopez, A. Ramon, and B. Kabert for permit assistance. They also thank M. J. Rivera-Rodriguez, F. B. Torres-Toledo, C. K. Ellis, S. R. Johnson, C. K. Wickham, C. G. Payne, W. E. Bruce, J. S. Humphrey, H. M. Northcutt, C. L. Zimmerman, C. D. Thomas, and J. K. Reynolds for exceptional field assistance.

\section{SUPPLEMENTARY MATERIAL}

Supplementary material for this article is online at http://dx.doi.org/10.7589/2019-03-077. 


\section{LITERATURE CITED}

Ballesteros C, Sage M, Fisher P, Massei G, Mateo R, De la Fuente J, Rossi S, Gortázar C. 2013. Iophenoxic acid as a bait marker for wild mammals: Efficacy and safety considerations. Mammal Rev 43:156-166.

Berentsen AR, Johnson SR, Gilbert AT, VerCauteren KC. 2015. Exposure to rabies in small Indian mongooses (Herpestes auropunctatus) from two regions in Puerto Rico. J Wildl Dis 51:896-900.

Berentsen AR, Johnson SR, VerCauteren KC. 2014. Bait matrix flavor preference by mongoose (Herpestes auropunctatus) in Puerto Rico: Implications for oral rabies vaccination. Caribb J Sci 48:52-58.

Berentsen AR, Nelson KM, Chipman RB, Vos A, Ortmann S, Gruver K, Boyd F, Sugihara RT, Payne CG, Volker S, et al. 2017. Evaluation of oral rabies vaccine bait uptake by small Indian mongooses: Preliminary results from the lab and field. In: Proceedings of the 28th international conference on rabies in the Americas, Calgary, Alberta, Canada, 2226 October, p. 63 [Abstract].

Berentsen AR, Sugihara RT, Payne CG, Leinbach I, Volker SF, Vos A, Ortmann S, Gilbert AT. 2019. Analysis of iophenoxic acid analogues in small Indian mongoose (Herpestes auropunctatus) sera for use as an oral rabies vaccination biological marker. J Vis Exp 147:59373.

Blanton JD, Meadows A, Murphy SM, Manangan J, Hanlon CA, Faber M-L, Dietzschold B, Rupprecht CE. 2006. Vaccination of small Asian mongoose (Herpestes javanicus) against rabies. J Wildl Dis 42 : 663-666.

Briscoe JA, Syring R. 2004. Techniques for emergency airway and vascular access in special species. Semin Avian Exot Pet Med 13:118-131.

Díaz OA. 2011. Cabo Rojo National Wildlife Refuge comprehensive conservation plan. US Department of Interior, Fish and Wildlife Service, Atlanta, Georgia, $180 \mathrm{pp}$.

Johnson SR, Berentsen AR, Ellis C, Davis A, VerCauteren KC. 2016. Estimates of small Indian mongoose densities: Implications for rabies management. Wildl Manage 80:37-47.

Kreeger TJ, Arnemo JM. 2012. Handbook of wildlife chemical immobilization. 4th Ed. Terry J. Kreeger, Sybille, Wyoming, 448 pp.

Ma X, Monroe BP, Cleaton JM, Orciari LA, Li Y, Kirby JD, Chipman RB, Petersen BW, Wallace RM, Blanton JD. 2018. Rabies surveillance in the United States during 2017. J Am Vet Med Assoc 253:15551568.

Pedersen K, Gilbert AT, Wilhelm ES, Nelson KM, Davis AJ, Kirby JD, VerCauteren KC, Johnson SR, Chipman RB. 2019. Effect of high-density oral rabies vaccine baiting on rabies virus neutralizing antibody response in raccoons (Procyon lotor). J Wildl Dis 55: 399-409.

Pimentel D. 1955. Biology of the Indian mongoose in Puerto Rico. J Mammal 36:62-68.

Seetahal JFR, Vokaty A, Vigilato MAN, Carrington CVF, Pradel J, Louison B, Sauers AV, Roopnarine R, Arrebato JCG, Millien MF, et al. 2018. Rabies in the Caribbean: A situational analysis and historic review. Trop Med Infect Dis 3:E89.

Slate D, Rupprecht CE, Rooney JA, Donovan D, Lein DH, Chipman RB. 2005. Status of oral rabies vaccination in wild carnivores in the United States. Virus Res 111:68-76.

Thulke H-H, Eisinger D. 2008. The strength of 70\%: Revision of a standard threshold of rabies control Dev Biol (Basel) 131:291-298.

Tierkel ES, Arbona G, Rivera A, De Juan A. 1952. Mongoose rabies in Puerto Rico. Public Health Rep 67:274-278.

Vos A, Kretzschamer A, Ortmann S, Lojkic I, Habla C, Müller T, Kaiser C, Hundt B, Schuster P. 2013. Oral vaccination of captive small Indian mongoose (Herpestes auropunctatus) against rabies. J Wildl Dis 49: 1033-1036.

Submitted for publication 26 March 2019.

Accepted 1 October 2019 